\title{
Variations in physiological and biochemical traits of oak seedlings grown under drought and ozone stress
}

\author{
Cotrozzi Lorenzo, Remorini Damiano, Pellegrini Elisa, Landi Marco, Massai Rossano, \\ Nali Cristina, Guidi Lucia* and Lorenzini Giacomo
}

Department of Agriculture, Food and Environment, Via del Borghetto, 80, 56124 Pisa, Italy

*Corresponding author, e-mail: lucia.guidi@unipi.it

Despite the huge biodiversity characterizing the Mediterranean environment, environmental constraints, such as high sunlight and high temperatures alongside with dry periods, makes plant survival hard. In addition, high irradiance leads to increasing ozone $\left(\mathrm{O}_{3}\right)$ concentrations in ambient air. In this era of global warming, it is necessary to understand the mechanisms that allow native species to tolerate these environmental constraints and how such mechanisms interact. Three Mediterranean oak species (Quercus ilex, Q. pubescens and Q. cerris) with different features (drought tolerant, evergreen or deciduous species) were selected to assess their biometrical, physiological and biochemical responses under drought and/or $\mathrm{O}_{3}$ stress $\left(80-100 \mathrm{nl}^{-1}\right.$ of $\mathrm{O}_{3}$ for $5 \mathrm{~h} \mathrm{~d}^{-1}$ for 77 consecutive days). Leaf visible injury appeared only under drought stress (alone or combined with $\mathrm{O}_{3}$ ) in all three species. Drought $\times \mathrm{O}_{3}$ induced strong reductions in leaf dry weight in Q. pubescens and Q. cerris $(-70$ and $75 \%$, respectively). Alterations in physiological (i.e. decrease in maximum carboxylation rate) and biochemical parameters (i.e. increase in proline content and build-up of malondialdehyde by-products) occurred in all the three species, although drought represented the major determinant. $Q$. ilex and $Q$. pubescens, which co-occur in dry environments, were more tolerant to drought and drought $\times \mathrm{O}_{3}$. Quercus ilex was the species in which oxidative stress occurred only when drought was applied with $\mathrm{O}_{3}$. High plasticity at a biochemical level (i.e. proline content) and evergreen habitus are likely on the basis of the higher tolerance of $Q$. ilex.

This article has been accepted for publication and undergone full peer review but has not been through the copyediting, typesetting, pagination and proofreading process, which may lead to differences between this version and the Version of Record. Please cite this article as doi: $10.1002 / \mathrm{ppl} 12402$

This article is protected by copyright. All rights reserved. 
Abbreviations $-\Delta_{\text {mean }}$, the deviation from the mean values; $\Phi_{\mathrm{CO} 2}$, quantum efficiency for $\mathrm{CO}_{2}$ assimilation; $\Phi_{\mathrm{PSII}}$, maximal photochemical efficiency in light adapted leaves; $\mathrm{A}$, net $\mathrm{CO}_{2}$ assimilation; $\mathrm{A}_{380}, \mathrm{CO}_{2}$ assimilation at light saturation level and $380 \mu \mathrm{ll}^{-1} \mathrm{CO}_{2}$; ANOVA, analysis of variance; Chl, chlorophyll; $\mathrm{Ch}_{\mathrm{TOT}}$, total chlorophyll; $\mathrm{C}_{\mathrm{i}}$, intercellular $\mathrm{CO}_{2}$ concentration; $\mathrm{DW}$, dry weight; $\mathrm{F}_{0}$, minimal fluorescence yield in dark-adapted leaves; $F_{m}$ and $F_{m}{ }^{\prime}$, maximum fluorescence yield in darkand light-adapted leaves; $F_{s}$, fluorescence yield in steady-state conditions; $F_{v}$, variable fluorescence yield; $\mathrm{F}_{\mathrm{v}} / \mathrm{F}_{\mathrm{m}}=$ potential PSII photochemical efficiency; $\mathrm{g}_{\mathrm{s}}$, stomatal conductance; LSD, least significant difference; MDA, malondialdehyde; NPQ, non-photochemical quenching; PAR, photosynthetic active radiation; $\mathrm{PD}_{\mathrm{w}}$, leaf water potential determined at pre-dawn; PI, plasticity index; PSII, photosystem II; Rubisco, ribulose-1,5-bisphosphate carboxylase/oxygenase; TBARS, thiobarbituric acid reactive substances; TCA, trichloroacetic acid; VAZ, violaxanthin+anteraxanthin+zeaxanthin; $\mathrm{V}_{\mathrm{cmax}}$, apparent maximum rate of carboxylation activity by Rubisco; $\mathrm{WUE}_{\mathrm{i}}$, intrinsic water use efficiency.

\section{Introduction}

An increase in the frequency and severity of drought events in several regions, especially in the Mediterranean basin, has been predicted to occur in the near future (Bussotti et al. 2014a and b). Low water availability usually occurs concurrently with high sunlight and high temperatures during the Mediterranean summer, in climatic conditions that favor ozone $(\mathrm{O} 3)$ photochemical production (Butkovic et al. 1990).

Under drought, plants usually suffer from the impairment of many physiological processes at the whole-plant level and in the structure and ultra-structure of cell organelles (Ahuja et al. 2010, Harb et al. 2010). Drought results in (i) a decrease in photosynthesis and growth (Hu et al. 2010, Pinheiro and Chaves 2011); (ii) stomatal closure (Hoshika et al. 2013a); (iii) cell dehydration (Manes et al. 2006); (iv) excess excitation energy (Fini et al. 2012); (v) massive production of reactive oxygen species (ROS, Jubani-Marí et al. 2010); and, finally, (vi) necrosis (Fini et al. 2013). Similar effects have also been attributed to $\mathrm{O}_{3}$ pollution (Hoshika et al. 2012 and 2013b, Dumont at al. 2013, Pellegrini et al. 2013, Gottardini et al. 2014, Vahisalu et al. 2010).

Much progress has been made in understanding the effects of a single stress, including drought and $\mathrm{O}_{3}$, on tree performance. However, the effects of interacting stresses cannot be adequately assessed from the combination of unifactorial responses. This is because drought $/ \mathrm{O}_{3}$ interactions are highly variable in their antagonistic, additive, or synergistic effects on trees' biochemical and ecophysiological processes (Matyssek et al. 2005). Some investigations have focused on the interactions of drought and $\mathrm{O}_{3}$ to determine putative mechanisms through which low water availability affects $\mathrm{O}_{3}$ damage (Desotgiu et al. 2012, Hoshika et al. 2013a, Pollastrini et al. 2013 and 2014, Gerosa et al. 2014, Li et al. 2015).

However, few studies have focused on understanding the drought $/ \mathrm{O}_{3}$ interactions on biochemical

This article is protected by copyright. All rights reserved. 
responses of trees. Conifers have been investigated (e.g. Kronfuss et al. 1998, Alonso et al. 2001, Haberer et al. 2008, Nikolova et al. 2010) and even more rarely in oak species of the Mediterranean basin (e.g. Kurz et al. 1998, Vitale et al. 2008, Calderòn Guerrero et al. 2013, Alonso et al. 2014). Unlike for biochemical findings, there have been many studies on the ecophysiological effects of drought $/ \mathrm{O}_{3}$ on trees, although the results being sometimes contradictory. It is believed that drought stress might counteract adverse $\mathrm{O}_{3}$ effects through its influence on reducing stomata aperture (Grünehage and Jäger 2003). For example, in saplings of Quercus ilex exposed to acute $\mathrm{O}_{3}$ in growth chambers and previously drought-stressed, Vitale et al. (2008) showed that there were lower $\mathrm{O}_{3}$ uptake fluxes for drought-stressed plants compared to their well-watered counterparts. Pollastrini et al. (2013) reported a similar antagonistic interaction in $\mathrm{O}_{3}$-sensitive poplar clones exposed to $\mathrm{O}_{3}$ in open-top chambers and drought-stressed.

In contrast, other results suggest that drought does not protect trees from $\mathrm{O}_{3}$ effects, but further exacerbates $\mathrm{O}_{3}$ damage. In fact, in seedlings of two subspecies of Q. ilex (ssp. ilex and ssp. ballota) exposed continuously to several $\mathrm{O}_{3}$ treatments in open-top chambers and drought, Alonso et al. (2014) reported that the combination of $\mathrm{O}_{3}$ and drought caused further decreases in accumulated aboveground biomass, although no additive effects were observed in terms of gas exchange and root biomass. Li et al. (2015) reported a similar interaction in seedlings of Acer truncatum exposed continuously to $\mathrm{O}_{3}$ in open-top chambers and drought. In Fagus sylvatica plants exposed to $\mathrm{O}_{3}$ treatment in large-scale fumigation chambers and subsequently drought-stressed (the plants were deprived of water for a period of time), Pearson and Mansfield (1993) reported that the combination of $\mathrm{O}_{3}$ and drought failed to induce the increase in stomatal resistance observed in $\mathrm{O}_{3}$-treated, well-watered plants. . In these cases, the effects observed depended on (i) timing, (ii) intensity, and (iii) order of exposure to the stressors.

The effects of stress interaction on Mediterranean vegetation are of particular interest given that these species are genetically equipped to withstand severe oxidative stress (Bussotti et al. 2014a) and to respond plastically to environmental change (Matesanz and Valladares 2014). Bussotti et al. (2015) reviewed the literature concerning the identification and the quantification of functional traits associated with drought resistance on the main tree species. Oaks (belonging to the genus Quercus which includes evergreen but also deciduous species) are considered as species that are well acclimated to cope with several environmental stressors (Corcobado et al. 2014) due to their phenotypic plasticity, despite a species-specific degree of tolerance. Holm oak (Q. ilex) is the most widely studied evergreen broadleaved species in terms of provenance trials and has been defined as "drought avoidant" and "water saving" with regard to its ecophysiological behavior (Bussotti et al. 2002). However, negative effects of drought have also been reported in Q. ilex (Pesoli et al. 2003, Gimeno et al. 2008). Downy oak (Q. pubescens) is a drought tolerant, winter deciduous species that occurs alongside Q. ilex in the Mediterranean basin (Damesin and Rambal 1995), however negative effects of drought have been reported regarding its photosynthetic, hydric and biometric parameters

This article is protected by copyright. All rights reserved. 
(Arend et al. 2011, 2013). Another winter deciduous tree, Turkey oak (Q. cerris), is present over a wide range of environments (south-east Europe and Asia Minor) as a result of its fast-growing ability and less drought tolerant nature (Manes et al. 2006). Of the oak species, Q. ilex is the only one that has been studied in depth in response to $\mathrm{O}_{3}$ and the negative effects of the pollutant in terms of visible injury as well as biometric and physiological patterns (Manes et al. 1998, Inclán et al. 1999, Ribas et al. 2005a,b, Calatayud et al. 2011, Alonso et al. 2014).

In this study we assessed various biometric, physiological and biochemical features in three oak species (Q. ilex, evergreen and drought tolerant; Q. pubescens, deciduous and drought tolerant, $Q$. cerris, deciduous, fast growing, but less drought tolerant) exposed to drought and chronic $\mathrm{O}_{3}$. Our aim was to answer the following three questions: (i) do drought and $\mathrm{O}_{3}$ interact with each other? (ii) is the effect of unifactorial and/or combined stressors similar in all three oaks? (iii) can phenotypic plasticity, with particular regard to physiological traits, lead to species-specific differences in the ability to counteract the deleterious effect of drought $\times \mathrm{O}_{3}$ ?

\section{Materials and methods}

\section{Plant growth, and ozone and drought treatments}

Experimental activities were conducted in the field-station of San Piero a Grado, Pisa $\left(43^{\circ} 40^{\prime} \mathrm{N}\right.$, $10^{\circ} 21^{\prime} \mathrm{E}$ ), Italy. Three hundred 3-year-old saplings of three Quercus species (Q. ilex, Q. pubescens and Q. cerris) were potted (6.5-1 pots) in a growing medium containing a mixture of standard soil Einhetserde Topfsubstrat ED 63 grob (peat and clay, 34\% organic C, $0.2 \%$ organic $\mathrm{N}$ and $\mathrm{pH}$ of $3.8-$ 6.8) and sand (3.5:1 in volume). The pots were placed in a greenhouse under controlled irrigation for two months in air filtered through active charcoal $\left[\mathrm{O}_{3}\right.$ concentration was negligible, below $5 \mathrm{nl} \mathrm{l}^{-1}$, as measured by an $\mathrm{O}_{3}$ analyzer (Monitor Labs, mod. 8810, San Diego, CA, USA)]. Two weeks before the beginning of fumigation, half of the plants received $30 \%$ of the effective evapotranspiration daily, whereas the other half received $100 \%$ of the evapotranspiration.

On 7 June 2013 uniformly sized plants were divided into four sets: 20 plants were catalogued as the control set and regularly irrigated to a maximum soil water holding capacity and exposed to charcoal filtered air $\left(\mathrm{WW} / \mathrm{O}_{3}-\right) ; 20$ plants were water stressed as reported above and exposed to charcoal filtered air (WS/O $\mathrm{O}_{3}-$ ); 20 plants were regularly irrigated and $\mathrm{O}_{3}$ fumigated $\left(\mathrm{WW} / \mathrm{O}_{3}+\right)$; and 20 plants were water stressed and $\mathrm{O}_{3}$ fumigated $\left(\mathrm{WS} / \mathrm{O}_{3}+\right)$. Plants were transferred into four controlled environment fumigation facilities which were ventilated with charcoal filtered air ( 2 boxes of $\mathrm{WW} / \mathrm{O}_{3}-$ and of WS/O $3^{-}$, respectively) or treated with $\mathrm{O}_{3}$ (2 boxes of $\mathrm{WW} / \mathrm{O}_{3}+$ and of $\mathrm{WS} / \mathrm{O}_{3}+$, respectively). The water-stress treatment was applied to the $\mathrm{WS} / \mathrm{O}_{3}-$ and $\mathrm{WS} / \mathrm{O}_{3}+$ sets until the end of the exposure, whereas the $\mathrm{WW} / \mathrm{O}_{3}-$ and $\mathrm{WW} / \mathrm{O}_{3}+$ sets were kept at field water capacity. The entire methodology of $\mathrm{O}_{3}$ exposure was performed according to Nali et al. (2004). In order to simulate a possible future seasonal trend of $\mathrm{O}_{3}$, plants were exposed to increasing concentrations $(80-100 \pm 13 \mathrm{nl}$ $\left.\mathrm{1}^{-1}\right)$ of pollutant for 77 consecutive days $\left(5 \mathrm{~h} \mathrm{~d}^{-1}\right.$, in form of a square wave between 10:00 and 15:00

This article is protected by copyright. All rights reserved. 
GMT). At the end of the fumigation period, photosynthetic (on the young fully expanded leaves) and hydric parameters were measured. Finally, leaves of five plants per species and per treatment were mixed, divided into aliquots, stored at $-20^{\circ} \mathrm{C}$ and subsequently lyophilized for chemical analyses.

\section{Ecophysiological measurements}

Water potential $\left(\Psi_{\mathrm{w}}\right)$ was measured on one leaf per plant before dawn (PD) by a Scholander-type pressure chamber (PMS model 600, PMS Instrument Company, Albany, OR, USA), using the precautions of Turner and Long (1980).

Net $\mathrm{CO}_{2}$ assimilation rate $(A)$, stomatal conductance $\left(\mathrm{g}_{\mathrm{s}}\right)$ and intercellular $\mathrm{CO}_{2}$ concentration $\left(\mathrm{C}_{\mathrm{i}}\right)$ were determined using a LI-6400 portable photosynthesis system equipped with a $2 \times 3 \mathrm{~cm}$ chamber and 6400-02B LED light source (Li-Cor Inc., Lincoln, NE, USA), operating at $380 \mu 1^{-1}$ ambient $\mathrm{CO}_{2}$ concentration and saturating light conditions (photosynthetic active radiation, PAR about $1200 \mu \mathrm{mol}$ photons $\mathrm{m}^{-2} \mathrm{~s}^{-1}$ ). When the leaves did not cover completely the LI-6400 photosynthesis chamber, used sections were removed to estimate their exact area. Areas were calculated from scaled pictures, taken immediately after being removed, using the image analysis software ImageJ. Light response curves for A were determined between 0 and $1800 \mu \mathrm{mol} \mathrm{m} \mathrm{m}^{-2} \mathrm{~s}^{-1}$ and were used to determine the light saturation level and the quantum efficiency for $\mathrm{CO}_{2}$ assimilation $\left(\Phi_{\mathrm{CO} 2}\right)$. Diurnal variations in $\mathrm{A}$ and $\mathrm{g}_{\mathrm{s}}$ were recorded in situ from 06:00 to 18:00 under ambient light and $\mathrm{CO}_{2}$ concentration. The responses of $\mathrm{A}$ to variations in internal $\mathrm{CO}_{2}$ concentration $\left(\mathrm{A} / \mathrm{C}_{\mathrm{i}}\right.$ curves) were performed as in Sharkey (1985). Measurements were taken with an infrared gas analyzer (CIRAS-2, PP-System International, Amesbury, MA, USA). The apparent maximum rate of carboxylation by ribulose-1,5-bisposphate carboxylase/oxygenase (Rubisco), $V_{c \max }$, was then estimated by the analysis of $A / C_{i}$ curves.

Chlorophyll (Chl) fluorescence imaging was obtained using an Imaging-PAM chlorophyll fluorometer (Walz, Effeltrich, Germany) on the leaf area. A charge-coupled device camera with a resolution of $640 \times 480$ pixels collected the fluorescence signal emitted by dark-adapted leaves over a 30-minute period. The maximum efficiency of photosystem II (PSII) photochemistry was calculated as $F_{v} / F_{m}=\left(F_{m}-F_{0}\right) / F_{m}$, where $F_{v}$ is the variable fluorescence, $F_{m}$ is the maximum fluorescence of darkadapted leaves, and $\mathrm{F}_{0}$ is the minimal fluorescence yield in dark-adapted leaves. The $\mathrm{F}_{0}$ values were recorded with a weak measuring beam $\left(0.1 \mu \mathrm{mol} \mathrm{m}^{-2} \mathrm{~s}^{-1}\right)$. The maximum fluorescence yield $\mathrm{F}_{\mathrm{m}}$ was determined with a saturating pulse of $8000 \mu \mathrm{mol} \mathrm{m} \mathrm{m}^{-2}$ PPFD for 1-2 s. Quenching analysis was carried out at about $600 \mu \mathrm{mol} \mathrm{m} \mathrm{m}^{-2} \mathrm{~s}^{-1}$. Chl fluorescence images taken from illuminated leaves were used to calculate the operating photochemical efficiency of PSII $\left[\Phi_{\mathrm{PSII}}=\left(\mathrm{F}_{\mathrm{m}}{ }^{\prime}-\mathrm{F}_{\mathrm{s}}\right) / \mathrm{F}_{\mathrm{m}}{ }^{\prime}\right)$, where $\mathrm{F}_{\mathrm{m}}{ }^{\prime}$ is the maximal fluorescence in the light adapted state and $\mathrm{F}_{\mathrm{s}}$ is Chl fluorescence emission in steady-state conditions] (Genty et al. 1989). The values of steady-state Chl fluorescence $\left(\mathrm{F}_{\mathrm{s}}\right)$ were normalized to dark-adapted basal rates $\left(\mathrm{F}_{0}\right)$ to take into account any difference between plants due to different leaf structure, Chl concentrations, etc. (Flexas et al. 2002). Non-photochemical quenching (NPQ) was calculated as $\mathrm{NPQ}=\left(\mathrm{F}_{\mathrm{m}}-\mathrm{F}_{\mathrm{m}}{ }^{\prime}\right) / \mathrm{F}_{\mathrm{m}}($ Bilger and Björkman 1990).

This article is protected by copyright. All rights reserved. 


\section{Biochemical analyses}

Proline content was determined following Bates et al. (1973), with some minor modifications. A hundred mg of lyophilized material was suspended in $1.5 \mathrm{ml}$ of $3 \%$ sulfosalicylic acid. The extraction was conducted by sonication of the samples at $70^{\circ} \mathrm{C}$ for $10 \mathrm{~min}$ three-times and samples were constantly shaken. The homogenates were centrifuged for $20 \mathrm{~min}$ at $16000 \mathrm{~g}$ at $20^{\circ} \mathrm{C}$. The supernatant was filtered through $0.2 \mu \mathrm{m}$ Minisart ${ }^{\circledR}$ SRT 15 aseptic filters and $0.8 \mathrm{ml}$ of the filtrate was mixed with equal volumes of glacial acetic acid $(0.8 \mathrm{ml})$ and $0.8 \mathrm{ml}$ of ninhydrin reagent $(1.25 \mathrm{~g}$ ninhydrin, $30 \mathrm{ml}$ of glacial acetic acid, $20 \mathrm{ml}$ of $\left.6 \mathrm{M} \mathrm{H}_{3} \mathrm{PO}_{4}\right)$ and incubated for $1 \mathrm{~h}$ at $100^{\circ} \mathrm{C}$. The reaction was stopped by placing the test tubes in ice-cold water. The samples were vigorously mixed with $1.6 \mathrm{ml}$ toluene. After $20 \mathrm{~s}$, the light absorption of the toluene phase was estimated at $520 \mathrm{~nm}$, using toluene as a blank. The proline concentration was determined using a standard curve.

Peroxidation was determined by TBARS (thiobarbituric acid reactive substances) (Döring et al. 2014). Lyophilized leaf samples (100 mg) were suspended in $1 \mathrm{ml}$ of $0.1 \%$ trichloroacetic acid (TCA) and the extraction was conducted by sonicating the samples at $70^{\circ} \mathrm{C}$ for 10 min three-times, keeping the samples shaken and centrifuging for $20 \mathrm{~min}$ at $16000 \mathrm{~g}$ at $20^{\circ} \mathrm{C}$. The supernatant was collected and $300 \mu \mathrm{l}$ was mixed with $1200 \mu \mathrm{l}$ of $20 \%$ TCA containing $0.5 \%$ thiobarbituric acid (TBA). The mixture was maintained at $90^{\circ} \mathrm{C}$ for $30 \mathrm{~min}$, quickly cooled and centrifuged for $10 \mathrm{~min}$ at $10000 \mathrm{~g}$ at $4^{\circ} \mathrm{C}$. The supernatant was used to determine malondialdehyde (MDA) concentration at $532 \mathrm{~nm}$, corrected for nonspecific turbidity by subtracting the absorbance at $600 \mathrm{~nm}$. The amount of MDA was calculated using an extinction coefficient of $155 \mathrm{mM}^{-1} \mathrm{~cm}^{-1}$.

Leaf pigments were determined by HPLC according to Döring et al. (2014), with some minor modifications. Fifty $\mathrm{mg}$ of lyophilized leaves were homogenized in $1 \mathrm{ml}$ of $100 \%$ HPLC-grade methanol and incubated overnight at $4^{\circ} \mathrm{C}$ in the dark. Samples were centrifuged for $15 \mathrm{~min}$ at $16000 \mathrm{~g}$ at $5^{\circ} \mathrm{C}$ and the supernatant was filtered through $0.2 \mu \mathrm{m}$ Minisart ${ }^{\circledR}$ SRT 15 aseptic filters and immediately analyzed. HPLC separation was performed at room temperature with a Dionex column (Acclaim 120, C18, $5 \mu \mathrm{m}$ particle size, $4.6 \mathrm{~mm}$ internal diameter x $150 \mathrm{~mm}$ length). The pigments were eluted using 100\% solvent A (acetonitrile/methanol, 75/25, v/v) for the first 14 min to elute all xanthophylls, and to separate lutein from zeaxanthin, followed by a 1.5 min linear gradient to $100 \%$ solvent B (methanol/ethylacetate, 68/32, v/v), 15 min with $100 \%$ solvent B, which was pumped for 14.5 min to elute $\mathrm{Chl} b$ and $\mathrm{Chl} a$ and $\beta$-carotene, followed by 2 min linear gradient to $100 \%$ solvent A. The flow-rate was $1 \mathrm{ml} \mathrm{min}$. The column was allowed to re-equilibrate in $100 \%$ solvent $\mathrm{A}$ for 10 min before the next injection. The pigments were detected by their absorbance at $445 \mathrm{~nm}$. To quantify the pigment content, known amounts of pure standard were injected into the HPLC system. An equation correlating the peak area to pigment concentration was formulated. The data were processed using Dionex Chromeleon software.

This article is protected by copyright. All rights reserved. 


\section{Plant biomass}

Above- and below-ground plant biomass production of five plants per treatment was harvested at the end of the experiment for each species. Dry plant material was obtained after drying the material in an oven at $70^{\circ} \mathrm{C}$ for $72 \mathrm{~h}$.

\section{Statistical analysis}

The experiment was set up following a randomized design and the experimental plot consisted of one plant per container. Measurements were carried out on three replicates for each treatment and species (unless specified otherwise).

Following the Shapiro-Wilk $\mathrm{W}$ test, the effects of drought, $\mathrm{O}_{3}$ and their combination were determined by two-way analysis of variance (ANOVA) and Fisher's least significant difference (LSD) test, with a significance level of $P=0.05$ (GraphPad Software, San Diego, CA USA). In the case of measurements carried out for more than two time-points, data were analyzed using repeated three-way ANOVA measurements.

An index of phenotypic plasticity ranging from 0 to 1 was calculated for each variable and species as the difference between the minimum and the maximum mean values among treatments divided by the maximum mean value (Valladares et al. 2000). This index was calculated for each species so that changes in variables expressed in different units and with contrasting variation, ranges could be compared. A two-way ANOVA was applied between groups of variables (biometric, biochemical and leaf physiology as grouped in Table S7) and oak species.

\section{Results}

\section{Visible symptoms and growth response}

At the end of the exposure, no visible leaf injury was observed in $\mathrm{WW} / \mathrm{O}_{3}-$ and $\mathrm{WW} / \mathrm{O}_{3}+$ plants across the three species. Under drought (alone or in combination with $\mathrm{O}_{3}$ ), plants of Q. ilex, Q. pubescens and Q. cerris, showed lateral and tip yellow-brown necrosis in the youngest fully expanded leaves and the onset was 47, 28 and 33 days from the beginning of the treatment, respectively (Fig. 1). In addition, at the end of the experiment, all plants, with the exception of $\mathrm{WW} / \mathrm{O}_{3}-$, showed a marked phylloptosis. The reduction in leaf number was $-25,-60$ and $-51 \%$ in $\mathrm{WS} / \mathrm{O}_{3}+$ plants of $Q$. ilex, Q. pubescens and Q. cerris, respectively compared to $\mathrm{WW} / \mathrm{O}_{3}-$ plants (data not shown).

Biometric parameters are reported in Table S1. According to the two-way ANOVA analysis, the interaction between drought and $\mathrm{O}_{3}$ was significant for all parameters only in Q. pubescens: total dry weight, shoot to root ratio and leaf dry weight decreased in $\mathrm{WS} / \mathrm{O}_{3}-(-54,-44$ and $-70 \%$, respectively, compared to controls), in $\mathrm{WW} / \mathrm{O}_{3}+(-24,-19$ and $-20 \%)$ and in $\mathrm{WS} / \mathrm{O}_{3}+$ plants $(-64,-31$ and $-70 \%)$. In $Q$. cerris, shoot to root ratio and leaf dry weight significantly decreased due to drought ( -29 and $50 \%$, respectively) and $\mathrm{O}_{3}(-43$ and $-38 \%)$. Combined factors reduced only leaf dry weight $(-75 \%)$ in Q. cerris, but did not significantly change any parameters in $Q$. ilex. In the latter species, drought

This article is protected by copyright. All rights reserved. 
alone induced a different partitioning in biomass allocation (as the shoot/root ratio significantly decreased) and a decrease in total and leaf dry weight. $\mathrm{O}_{3}$ alone was significant only for the shoot/root ratio and leaf dry weight.

\section{Water status, proline and MDA-by product content}

Drought (alone and combined with $\mathrm{O}_{3}$ ) appeared to be the main determinant in reducing $\mathrm{PD \Psi}_{\mathrm{w}}$ in all the species under investigation (Table S2). Only in Q. pubescens, did $\mathrm{O}_{3}$ induce a slight but significant effect on water status. Fig. 2 a shows that $\mathrm{WS} / \mathrm{O}_{3}+$ saplings of the three species had lower values of $\mathrm{PD} \Psi_{\mathrm{w}}$ than $\mathrm{WW} / \mathrm{O}_{3}-$ saplings (from 2- to 3 -fold).

Proline content significantly increased in $\mathrm{WS} / \mathrm{O}_{3}-$ plants, especially in $Q$. pubescens (3 fold higher compared with $\mathrm{WW} / \mathrm{O}_{3}-$ individuals) (Fig. 2b). Following $\mathrm{O}_{3}$ exposure, proline content significantly increased in $Q$. ilex $\left(+117 \%\right.$, in comparison to $\left.\mathrm{WW} / \mathrm{O}_{3}-\right)$, however, the strongest accumulation of proline was observed in $\mathrm{WS} / \mathrm{O}_{3}+$ plants of Q. ilex and Q. cerris (about 7-and 2-fold compared to controls, respectively) (Fig. 2b).

In $Q$. pubescens and $Q$. cerris, a significant increase in MDA by-products was observed in $\mathrm{WS} / \mathrm{O}_{3}-\left(+10\right.$ and $+25 \%$, respectively), WW/O $\mathrm{O}_{3}+(+11$ and $+17 \%)$ and more in $\mathrm{WS} / \mathrm{O}_{3}+$ plants (about $+30 \%$ in both species) (Fig. 2c). In Q. pubescens the increase observed in $\mathrm{WS} / \mathrm{O}_{3}-$ and $\mathrm{WW} / \mathrm{O}_{3}+$ plants was significantly lower than that recorded in $\mathrm{WS} / \mathrm{O}_{3}+$. In $Q$. ilex, the level of MDA by-products significantly increased only in $\mathrm{WS} / \mathrm{O}_{3}+$ plants ( $+23 \%$ compared to the controls).

\section{Gas exchanges and chlorophyll $a$ fluorescence}

In WW/ $/ \mathrm{O}_{3}-$ plants of Q. ilex and Q. pubescens, $\mathrm{g}_{\mathrm{s}}$ peaked at 10:00 a.m. while in $Q$. cerris $\mathrm{g}_{\mathrm{s}}$ peaked at 12:00 (Figs. $3 \mathrm{a}, \mathrm{c}$ and e). Diurnal trends of $\mathrm{A}$ in $\mathrm{WW} / \mathrm{O}_{3}-$ plants followed those of $\mathrm{g}_{\mathrm{s}}$ (Figs. $3 \mathrm{~d}$ and $\mathrm{f}$ ) even though in Q. ilex A peaked in the range of 10:00 a.m. to 14:00 p.m. (Fig. 3 b). Notably, the daily reduction in $\mathrm{A}$ and $\mathrm{g}_{\mathrm{s}}$ in all the species was markedly pronounced in $\mathrm{WS} / \mathrm{O}_{3}-$ and $\mathrm{WS} / \mathrm{O}_{3}+$ plants, while plants treated with $\mathrm{O}_{3}$ alone were less affected as compared to the other treatments (Figs. 3a-f). In all species, drought and $\mathrm{O}_{3}$ (alone or in combination) highly affected the diurnal pattern of A (Figs. 3b, d and f; Table S3).

Drought and/or $\mathrm{O}_{3}$ also induced negative effects on the $\mathrm{CO}_{2}$ assimilation rate at light saturation $\left(\mathrm{A}_{380}\right)$ (Fig. 4a and Table S4). In WS/O $\mathrm{O}_{3-}, \mathrm{WW} / \mathrm{O}_{3}+$ and $\mathrm{WS} / \mathrm{O}_{3}+$ plants, significant reductions were recorded in $Q$. ilex (-86, -37 and $-83 \%$ compared to controls) and in $Q$. cerris $(-65,-39$ and $-63 \%)$, but not significantly in $Q$. pubescens (only drought induced a statistically significant effect), in which a high variability was found. According to the two-way ANOVA analysis, the interaction between drought and $\mathrm{O}_{3}$ was significant for $\mathrm{g}_{\mathrm{s}}$ in all species except for $Q$. pubescens. WS $/ \mathrm{O}_{3}-$ plants had a significant reduction in $\mathrm{g}_{\mathrm{s}}$ in all of the species $(P<0.001, P<0.01$ and $P<0.01$ for $Q$. ilex, Q. pubescens and Q. cerris, respectively) (Fig. $4 \mathrm{~b}$ and Table S4) whereas $\mathrm{g}_{\mathrm{s}}$ decreased only in $Q$. cerris $\mathrm{WW} / \mathrm{O}_{3}+$ plants $(P<0.01)$. The interaction between drought and ozone was significant only in $Q$. ilex and $Q$.

This article is protected by copyright. All rights reserved. 
cerris (Table S4). According to the two-way ANOVA analysis, the interaction between drought and $\mathrm{O}_{3}$ was significant for the intrinsic water use efficiency ( $\mathrm{WUE}_{\mathrm{i}}$ ) only in $Q$. pubescens. $\mathrm{WUE}_{\mathrm{i}}$ decreased steeply in $\mathrm{WS} / \mathrm{O}_{3}+$ plants ( $-22 \%$ compared to controls) and increased strongly in $\mathrm{WS} / \mathrm{O}_{3}-$ plants. By contrast, it remained unchanged or even decreased $(-42 \%)$ in Q. cerris and Q. ilex, respectively (Fig. 4c). Drought and/or $\mathrm{O}_{3}$ also decreased apparent $\mathrm{V}_{\mathrm{cmax}}$ in all the species (Fig. 4d; Table S4). No significant changes in $\mathrm{C}_{\mathrm{i}}$ were observed in any of the species regardless of the treatment (data not shown).

In the dark-adapted leaves of all control plants, the mean maximal photochemical efficiency $\left(\mathrm{F}_{\mathrm{v}} / \mathrm{F}_{\mathrm{m}}\right.$ ratio) was $0.83 \pm 0.009$ (Fig. 5a), which lies in the range $\left(0.80 \leq \mathrm{F}_{\mathrm{v}} / \mathrm{F}_{\mathrm{m}} \leq 0.86\right)$ reported by Björkman and Demmig (1987) for healthy plants. In Q. pubescens, water shortage combined with $\mathrm{O}_{3}$ slowly reduced the ratio that remained in the range reported above (Fig. 5a). In WS/O $\mathrm{O}_{3}+$ Q. cerris plants, a slight reduction in this ratio $(-7 \%)$ was observed, whereas there was a reduction in $Q$. ilex as well, although it was not significant because the two stressors contributed similarly in decreasing $\mathrm{F}_{\mathrm{v}} / \mathrm{F}_{\mathrm{m}}$ (Table S5). A reduction in $\Phi_{\mathrm{PSII}}$ in $\mathrm{WS} / \mathrm{O}_{3}+$ plants of $Q$. ilex and $Q$. pubescens was observed, while in Q. cerris it was not significant (Fig. 5b; (Table S5).

In all species drought significantly reduced $\Phi_{\mathrm{PSII}}$, while the effect of $\mathrm{O}_{3}$ was significant only in $Q$. pubescens (Fig. 5b and Table S5). The two-way ANOVA analysis revealed that the interaction between drought and $\mathrm{O}_{3}$ was significant for NPQ in all species except in $Q$. cerris. Dynamic photoinhibition induced by the combination of both stresses led to an increase in thermal dissipation of excess excitation energy in Q. ilex, while a decrease was observed in Q. pubescens (Fig. 5c; Table S5). The highest value of NPQ was found in $\mathrm{WS} / \mathrm{O}_{3}$ - plants of $Q$. ilex (2.6 $\pm 0.63 v \mathrm{~s} 1.5 \pm 0.58$; Fig. $\left.5 \mathrm{c}\right)$.

In WS $/ \mathrm{O}_{3}-, \mathrm{WW} / \mathrm{O}_{3}+$ and $\mathrm{WS} / \mathrm{O}_{3}+$ plants of $Q$. ilex, the $\mathrm{F}_{\mathrm{s}} / \mathrm{F}_{0}$ ratio significantly decreased. The latter parameter did not change in $Q$. cerris plants and significantly increased in $\mathrm{WS} / \mathrm{O}_{3}-(+39 \%)$, $\mathrm{WW} / \mathrm{O}_{3}+(+68 \%)$ and $\mathrm{WS} / \mathrm{O}_{3}+(+28 \%)$ plants of Q. pubescens (Fig. 5d; Table S5). The degree of partitioning of the reductive power between $\mathrm{CO}_{2}$ assimilation and non-assimilative processes (revealed by $\Phi_{\mathrm{PSI}} / \Phi_{\mathrm{CO} 2}$ ratio) increased following the combination of the two stresses in $Q$. ilex and $Q$. pubescens ( +69 and $+268 \%$, respectively). In the latter species, a strong and significant increase was also observed under drought ( $+447 \%$ ). No changes were observed in $\mathrm{WS} / \mathrm{O}_{3}+$ plants of $Q$. cerris (Fig. 5e; Table S5).

\section{Pigment content}

The two-way ANOVA analysis revealed that the interaction between drought and $\mathrm{O}_{3}$ was significant for total chlorophyll $\left(\mathrm{Chl}_{\mathrm{TOT}}\right)$ in all species except in Q. pubescens. In $\mathrm{WS} / \mathrm{O}_{3}-$ and $\mathrm{WS} / \mathrm{O}_{3}+$ plants of Q. ilex, $\mathrm{Chl}_{\mathrm{TOT}}$ content decreased significantly $(-13$ and $-20 \%$, respectively), while no differences were observed in $\mathrm{WW} / \mathrm{O}_{3}+$ plants (Table S6). A strong increase of $\mathrm{Ch} \mathrm{T}_{\mathrm{TOT}}$ was found in $\mathrm{WS} / \mathrm{O}_{3}-$, $\mathrm{WW} / \mathrm{O}_{3}+$ and $\mathrm{WS} / \mathrm{O}_{3}+$ plants of $Q$. cerris $(+75,+38$ and $+81 \%$ respectively). The ratio $\mathrm{Chl} a / b$ and VAZ content remained unchanged after all the treatments in all the species with few exceptions (Table

This article is protected by copyright. All rights reserved. 
S6). In $Q$. cerris, drought was statistically significant in relation to $\mathrm{Chl} a / b$, and in $Q$. pubescens, drought and ozone were statistically significant in relation to VAZ.

\section{Phenotypic plasticity}

In all the species biometric parameters PI values were significantly higher that physiological and biochemical respectively (Tables S7 and S8). The phenotypic response to stress in terms of deviation from the mean PI values $\left(\Delta_{\text {mean }}\right)$ was lower in $Q$. cerris $(-0.05$ compared to +0.03 both in $Q$. ilex and Q. pubescens), especially for leaf physiological features $(-0.11)$ compared to the other species $(+0.05$ and +0.09 for $Q$. ilex and Q. pubescens, respectively) (Table S7). In the same way, $\Delta_{\text {mean }}$ for leaf water potential was lower $(-0.09)$ in $Q$. cerris than in the other oaks $(+0.03$ and +0.07 for $Q$. ilex and $Q$. pubescens, respectively) (Table S7). Within all the biochemical parameters, PI and $\Delta_{\text {mean }}$ for proline in Q. ilex were 0.85 and +0.19 respectively, and strongly contributed to increasing the mean values of all the biochemical parameters (Table S7).

\section{Discussion}

Drought and $\mathrm{O}_{3}$, which are two stressors typically experienced by plants in the Mediterranean basin during the warm season, may restrict $\mathrm{CO}_{2}$ photoassimilation and plant growth (Vitale et al. 2008, Pollastrini et al. 2013, Alonso et al. 2014). Their effects change however according to the genotype and environmental conditions, such as the duration of the stress, its intensity, and the concurrence of other constrained conditions. Research on the interaction between drought and $\mathrm{O}_{3}$ has led to contrasting results. In some cases, drought-induced stomatal closure limited the $\mathrm{O}_{3}$ flux to leaves and the consequent $\mathrm{O}_{3}$-induced damage (Vitale et al. 2008). In other cases, a water deficit did not cause a similar ameliorative effect (Ribas et al. 2005b). The model that predicts that drought-induced stomatal closure limits the entry of $\mathrm{O}_{3}$ into the leaf, preserving and/or reducing damage, appears too simplistic and not universally applicable. Consequently, the first question is "Do drought and ozone interact with each other?"

We found that the combination of drought and $\mathrm{O}_{3}$ had strong negative effects on most of the biometric and physiological parameters of the three oak species. However, the reduction in plant growth following the combination of the two stresses was attributable principally to drought, given that in all three species the plant biomass reduction is reasonably comparable in both $\mathrm{WS} / \mathrm{O}_{3}-$ and $\mathrm{WS} / \mathrm{O}_{3}+$ plants. However, the impact of $\mathrm{O}_{3}$ alone on growth seems to have been species-specific in view of the reduction of total dry weight in $Q$. pubescens. Gas exchange parameters also highlighted that oaks facing a combination of drought $\times \mathrm{O}_{3}$ had a significantly reduced $\mathrm{CO}_{2}$ assimilation rate, and to a similar extent to plants only experiencing water deficit. In all the oak species tested in this work, the limitations in photoassimilation were attributable to both the reduction in stomatal conductance and mesophyllic (biochemical and diffusional) alterations, i.e. unchanged $\mathrm{C}_{\mathrm{i}}$ and reduction in apparent

This article is protected by copyright. All rights reserved. 
$\mathrm{V}_{\text {cmax }}$. Plants submitted to drought and drought $\times \mathrm{O}_{3}$ endured a decrease in daily A and $\mathrm{g}_{\mathrm{s}}$ from control plants.

The $\mathrm{O}_{3}$ concentration applied did not give rise to the same dramatic effects induced by drought stress. However, alterations in daily assimilation rate and gas exchange parameters were observed in all three oaks species. Thus under the combination of drought and $\mathrm{O}_{3}$, despite the effects of drought is predominant, the effect of $\mathrm{O}_{3}$ might be not negligible. Besides similar effects on biomass and biomass partitioning, our results seem to indicate that drought has a less deleterious impact than drought $\times \mathrm{O}_{3}$ on some physiological parameters (i.e., photochemical PSII efficiency and intrinsic water use efficiency) in all the three species. Further biochemical responses as well as physiological adjustments are activated when $\mathrm{O}_{3}$ is added as a treatment for drought. In the light of the above, the second question is: "How differently did the three oak species respond to drought and drought $\times \mathrm{O}_{3}$ ?"

Following withholding water, all three species exhibited a greater decrease in PD $\Psi_{w}$. pubescens showed a strong increase in $\mathrm{WUE}_{\mathrm{i}}$, compared to its control. Conversely, $\mathrm{WUE}_{\mathrm{i}}$ had a significant decrease in the evergreen $Q$. ilex. In all three oaks, drought induced a different partitioning in biomass allocation observed through the significant reduction in the shoot/root ratio, particularly in Q. pubescens. The greater carbon partitioning to roots found in $Q$. pubescens is in agreement with previous findings (Nardini and Pitt 1999), which highlight that this species is able to tolerate severe water stress conditions by compensating water loss with an equal amount of water uptake. This drought avoidance strategy showed by $Q$. pubescens is made possible by the high hydraulic efficiency of the stem and roots under water stress (Nardini and Pitt 1999). However, when drought is combined with $\mathrm{O}_{3}$, Q. pubescens showed the strongest biomass reduction among all the species, and the putative ability to counteract water withholding was lost. This is confirmed by the significant reduction in $W_{U E}$ which remained unchanged in the other two species in comparison to the drought-stressed individuals. It is probable that the pronounced phylloptosis observed in Q. pubescens contributed to the decrease in $\mathrm{CO}_{2}$ assimilation, hence reducing the ability to maintain an efficient development of the root system.

A different picture emerged with regard to the evergreen $Q$. ilex, in which the drought $\times \mathrm{O}_{3}$ combination further increased the amount of carbon allocated to the root compared to that accumulated in the shoot (from 2.4 in WS/O $\mathrm{O}_{3}-$ to 1.6 in WS $/ \mathrm{O}_{3}+$ plants). In addition, in this species phyllotopsis was not as pronounced as in the other two deciduous oaks (data not shown). Finally, $Q$. cerris showed a similar behavior to that recorded in Q. ilex, but when concomitantly subjected to drought $\times \mathrm{O}_{3}$, root and shoot biomass partitioning was similar to that of the control plants. Thus, in terms of biomass accumulation and loss of $\mathrm{WUE}_{\mathrm{i}}$, Q. pubescens was the species in which the effect of drought $\times \mathrm{O}_{3}$ had the most deleterious impact. Besides the effects of these stressors on the biometric and $\mathrm{WUE}_{\mathrm{i}}$ traits of the three oak species, other physiological mechanisms that underline the behaviour of the different oak species under drought and drought $\times \mathrm{O}_{3}$ are evidenced. In $\mathrm{WS} / \mathrm{O}_{3}-$ and $\mathrm{WS} / \mathrm{O}_{3}+$ plants of $Q$. ilex, $\Phi_{\mathrm{PSII}}$ significantly decreased and the excess of excitation energy was effectively

This article is protected by copyright. All rights reserved. 
dissipated as non-photochemical quenching, i.e., an increase in NPQ. Notably, holm oak was the only species in which the oxidative stress did not increase under drought (unchanged MDA by-product values). However, in $\mathrm{WS} / \mathrm{O}_{3}+$ plants of $Q$. ilex, these mechanisms were not sufficient to prevent PSII photoinhibition and a significant decrease in $\mathrm{F}_{\mathrm{v}} / \mathrm{F}_{\mathrm{m}}$ was recorded, as already reported in this species under contrasting climatic conditions (xeric, continental and mesic sites) (Camarero et al. 2012). Consequently, an increase in oxidative stress was evident, as revealed by a significant build-up of MDA by-products. The strong increase in proline content ( $+600 \%$ compared to the controls) could have preserved Q. ilex plants from further oxidative damage. In fact proline not only facilitates water uptake under drought conditions (Ashraf and Foolad 2007), but also protects plant cells against reactive oxygen species accumulation under stress conditions (Filippou et al. 2014). The $\Phi_{\mathrm{PSII}} / \Phi_{\mathrm{CO} 2}$ ratio strongly increased following the combination drought $\times \mathrm{O}_{3}$ in Q. ilex plants, which indicates the activation of non-reductive processes that dissipate excitation energy, such as photorespiration which is high in this species (Tsonev et al. 2014). Such a pathway would be energetically favorable because the pathway assists in re-oxidation of the photosystems. $\alpha$-ketoglutaric acid, which is another metabolite connected to photorespiration, can be channeled via glutamate, into the biosynthesis of the osmolyte proline. This consequently highlights the relation between the response shown by Q. ilex and confirming the recorded increase in proline content.

Compared to the other oak species, Q. cerris had the lowest reduction in stomatal conductance and $\mathrm{A}_{380}$ in response to drought and drought $\times \mathrm{O}_{3}$. In addition, in $\mathrm{WS} / \mathrm{O}_{3}-$ and $\mathrm{WS} / \mathrm{O}_{3}+$ plants of $Q$. cerris, there was a strong reduction in $\Phi_{\mathrm{PSII}}$ which was not detected in $\mathrm{WW} / \mathrm{O}_{3}+$ plants. A response to drought and drought $\times \mathrm{O}_{3}$ shown by $Q$. cerris was the unchanged values of NPQ, which indicates that non-photochemical mechanisms aimed at preserving the photosynthetic apparatus against damage induced by high excitation energy, were not activated.

These features do not indicate that $Q$. cerris has a higher degree of tolerance compared to the other two species. Indeed, the unvaried $\mathrm{WUE}_{\mathrm{i}}$ and thus the non-controlled stomatal closure related to $\mathrm{CO}_{2}$ assimilation, could have contributed to an increase in MDA levels which were similarly (and with a similar extent) strongly increased both under drought, $\mathrm{O}_{3}$ and in combination. In addition, in $\mathrm{WS} / \mathrm{O}_{3}+$ of this species, the $\mathrm{F}_{\mathrm{v}} / \mathrm{F}_{\mathrm{m}}$ ratio decrease (compared to that of healthy control plants) was the highest among all the three species, suggesting a deep impairment of PSII efficiency. WS $/ \mathrm{O}_{3}-$ and $\mathrm{WS} / \mathrm{O}_{3}+$ leaves of $Q$. cerris showed a marked increase in the amount of chlorophyll content, probably as an attempt to increase the proportion of functional PSII reaction centers.

Finally, Q. pubescens plants, in which phylloptosis markedly pronounced as was the biomass reduction, showed a strong reduction in $\mathrm{CO}_{2}$ assimilation in both $\mathrm{WS} / \mathrm{O}_{3}-$ and $\mathrm{WS} / \mathrm{O}_{3}+$ plants. The decrease in $\Phi_{\text {PSII }}$ in $\mathrm{WS} / \mathrm{O}_{3}+$ plants (compared to drought alone) indicates that besides the photochemical processes, other electron sinks from PSII, such as photorespiration or the Mehler reaction, might not efficiently sustain the high electron transport rate when $\mathrm{O}_{3}$ was combined with

This article is protected by copyright. All rights reserved. 
drought. Quercus pubescens subjected to the experimental constraints in this work showed photoinhibition because of a lower capacity to develop an efficient NPQ pathway. In this species, the oxidative stress increased under all the treatments, similarly to Q. cerris. However, while in Q. cerris, the increment in MDA was strong under each treatment, for $Q$. pubescens the increment was only slight in $\mathrm{WS} / \mathrm{O}_{3}-$ and $\mathrm{WW} / \mathrm{O}_{3}+$, and became strong only in $\mathrm{WS} / \mathrm{O}_{3}+$ plants.

Plant plasticity is dependent on the environments that the plant inhabits (Bussotti et al. 2014a). Q. ilex and Q. pubescens appear to be the most plastic species in terms of phenotypic traits (Fig. 6). Conversely, $Q$. cerris, the species that is least adapted to drought because of the inherent differences of its natural habitat, exhibited a significantly reduced plasticity (Fig. 6).

As already reported (Valladares et al. 2002, Gratani et al. 2013), all these species are characterized by high values of PI for biometric traits. However, physiological and biochemical features are also likely to be involved in plant responses to environmental factors. $Q$. ilex and $Q$. pubescens appear to be the most plastic in terms of physiological parameters $\left(\Delta_{\text {mean }}=+0.05\right.$ and +0.09 , respectively) compared to $Q$. cerris (-0.11). Consequently, Q. cerris, which is usually found in habitats where drought is less frequent, exhibited less conservative water-use characteristics $\left(\Delta_{\text {mean }}=-\right.$ 0.09 for $\mathrm{PD}_{\mathrm{w}}$ ) probably in an attempt to combat the negative effect of drought with a pronounced phylloptosis.

These results are in agreement with those found by Tognetti et al. (2007), who reported that $Q$. cerris exhibited relatively high stomatal conductance, low $\mathrm{WUE}_{\mathrm{i}}$, and low soil-to-leaf hydraulic conductance. In addition, Q. cerris showed a stress-induced damage to photosynthetic apparatus and an increased oxidative stress following drought and/or $\mathrm{O}_{3}$, as attested by a very strong level of MDA by-products, even when unifactorial treatments were applied. The increase in Chl biosynthesis was the only alternative mechanism to a "wiser" water control in this species. Conversely, the other two species (usually considered more drought tolerant) maintained higher $P D \Psi_{w}$ than $Q$. cerris. Thus, due to their plasticity of physiological traits (in terms of $\Delta_{\text {mean }}$ values), they can adjust their physiology to harsher variations in water ability better than Q. cerris. Q. pubescens is in fact a thermophilous, xerophilous species and typically grows on dry, lime-rich soils in the sub-Mediterranean region, which is characterized by hot dry summers and mild dry winters (Damesin and Rambal 1995). Baldocchi et al. (2010) reported that $Q$. pubescens followed a similar drought-avoidance strategy to $Q$. ilex, but maximized gas exchange during a shorter growing season which thus induced a high transpiration rate throughout summer.

Physiological mechanisms do not protect Q. ilex or Q. pubescens against oxidative stress once drought occurs concomitantly with $\mathrm{O}_{3}$. However, the higher plasticity of biochemical traits found in $Q$. ilex compared to $Q$. pubescens, which is above all due to a high ability to modulate proline content under stress conditions, enabled $Q$. ilex to prevent oxidative stress under drought or $\mathrm{O}_{3}$ alone. However, this mechanism was less efficiently modulated in $Q$. pubescens, with MDA by-products

This article is protected by copyright. All rights reserved. 
strongly enhanced after the exposure to each stress alone.

Our dataset supports the hypothesis that Q. ilex was the most tolerant species to drought and $\mathrm{O}_{3}$ when applied as single factors. Its photosynthetic apparatus seems to be well adapted to withstand several environmental adverse conditions, as already reported by Garcia-Plazaola et al. (1999), which could explain its wider ecological distribution (Gratani et al. 2000, Crescente et al. 2002, Niinemets and Keenan 2014).

Given that global change may induce plastic responses in co-occurring Mediterranean species (Valladares et al. 2007), morpho-anatomical traits twinned with physiological plasticity could assist plant species in counteracting the negative effects of several stresses as in these species, despite not always completely preventing the occurrence of the oxidative load, as in $Q$. pubescens and Q. cerris. In this context, also the biochemical traits (i.e. content of chlorophyll, antioxidant enzymes, carotenoids, flavonoids), which depend on both the species and the environmental conditions (i.e. sunlight irradiance) at which leaves developed, are crucial for avoiding and countering oxidative damage during stress conditions (Munné-Bosch and Alegre 2000, Valladares and Pearcy 2002, Guidi et al. 2011, Bussotti et al. 2014a).

Consequently the third question is: "Is the slight difference of plasticity in terms of biochemical features found in Q. ilex (compared to Q. pubescens) enough to explain its superior ability (at least in terms of oxidative stress, i.e., MDA by-products) to counteract the deleterious effect of drought and $\mathrm{O}_{3}$ over Q. pubescens?"

The inherent differences between Q. ilex and Q. pubescens (evergreen and deciduous, respectively) further differentiate their plant responses. To fully exploit its long-lived leaves, it is essential for sclerophyllous holm oak to maintain its functionality during stress, also in an attempt to reduce the level of phylloptosis, which can be particularly onerous for an evergreen species. In fact, holm oak is the main sclerophyllous evergreen species in the Mediterranean area and is characterized by a xeromorphic leaf structure and an efficient stomatal control, which ensure tolerance to summer drought (Camarero et al. 2012, Calderòn Guerrero et al. 2013).

To conclude, climate change factors such as drought and $\mathrm{O}_{3}$ have contrasting effects when considered separately or combined. The chronic $\mathrm{O}_{3}$ concentration adopted in this experiment seemed to have a minor impact compared to drought on the responsiveness of the three oak species. This highlights that the plasticity of the plant species is dependent on the environment in which the plant inhabits. Plant species that inhabit environments characterized by seasonal variations in water availability with long periods of drought (i.e. Q. ilex and Q. pubescens), are usually more plastic under the same stress compared to those that rarely face the same stressor (Q. cerris).

Our dataset suggests that biochemical and physiological adjustments may reduce the impact of $\mathrm{O}_{3}$ when combined with the effect of water stress. Sclerophyllous habitus can further increase the tolerance to environmental constraints in Mediterranean areas.

This article is protected by copyright. All rights reserved. 


\section{Author contributions}

The work presented here was carried out in collaboration among all authors. GL and RM defined the research theme and obtained funding. LC, DR, EP and ML designed methods, carried out laboratory experiments, and analyzed the data. LG and $\mathrm{CN}$ co-designed experiments, discussed analyses, interpreted the results and wrote the paper. All authors have contributed to, seen and approved the manuscript.

Acknowledgements - This study was published in the framework of the PRIN 2010-11 project "Planning the green city in the global change era: urban tree functions and suitability for predicted future climates" (TreeCity, http://reecity.agr.unipi.it) and PRA 2015 project “Alberi urbani nell'era del Global Change". The authors are grateful to Francesca Alderighi, Elisa Garramone, Ilaria Mancini and Ludovica Ricottone for the technical support.

\section{References}

Ahuja I, de Vos RCH, Bones AM, Hall RD (2010) Plant molecular stress responses face climate change. Trends Plant Sci 15: 664-674

Alonso R, Elvira S, Castillo FJ, Gimeno BS (2001) Interactive effects of ozone and drought stress on pigments and activities of antioxidative enzymes in Pinus halepensis. Plant Cell Environ 24: 905916

Alonso R, Elvira S, Gonzalez-Fernandez I, Calvete H, Garcia-Gomez H, Bermejo V (2014) Drought stress does not protect Quercus ilex L. from ozone effects: results from a comparative study of two subspecies differing in ozone sensitivity. Plant Biol 16: 375-384

Arend M, Kuster T, Günthard-Goerg M, Dobbertin M, 2011. Provenance specific growth responses to drought and air warming in three European oak species (Quercus robur, Q. petraea and Q. pubescens). Tree Physiol 31: 287-297

Arend M, Brem A, Kuster T, Günthard-Goerg M, 2013. Seasonal photosynthetic responses of European Oaks to drought and elevated daytime temperature. Plant Biol 15: 169-176

Ashraf M, Foolad MR (2007) Roles of glycine betaine and proline in improving plant abiotic stress resistance. Environ Exp Bot 59: 206-216

Baldocchi DD, Ma S, Rambal S, Misson L, Ourcival J-M, Limousin J-M, Pereira J, Papale D (2010)

On the differential advantages of evergreenness and deciduousness in Mediterranean oak woodlands: a flux perspective. Ecol App 20:1583-1597

Bates LS, Waldren RP, Teare JD (1973) Rapid determination of free proline for water stress studies Plant Soil 39: 205-207

Bilger W, Björkman O (1990) Role of the xanthophyll cycle in photoprotection elucidated by measurements of light-induced absorbance changes, fluorescence and photosynthesis in leaves of Hedera canariensis. Photos Res 25: 173-185

This article is protected by copyright. All rights reserved. 
Björkman O, Demmig B (1987) Photon yield of $\mathrm{O}_{2}$ evolution and chlorophyll fluorescence characteristics at 77K among vascular plants of diverse origins. Planta 170: 489-504

Bussotti F, Bettini D, Grossoni P, Mansuino S, Nibbi R, Soda C, Tani C (2002) Structural and functional traits of Quercus ilex in response to water availability. Environ Exp Bot 47: 11-23

Bussotti F, Ferrini F, Pollastrini M, Fini A (2014a) The challenge of Mediterranean sclerophyllous vegetation under climate change: from acclimation to adaption. Environ Exp Bot 103: 80-98

Bussotti F, Pollastrini M, Holland V, Brüggemann W (2015) Functional traits and adaptive capacity of European forests to climate change. Environ Exp Bot 111: 91-113

Bussotti F, Pollastrini M, Killi D, Ferrini F, Fini A (2014b) Ecophysiology of urban trees in a perspective of climate change. Agrochimica 58: 247-268

Butkovic V, Cvitas T, Klasing L (1990) Photochemical ozone in the Mediterranean. Sci Total Environ 99: $145-151$

Calatayud V, Cerveró J, Calvo E, García-Brejio FJ, Reig-Armiñana J, Sanz MJ (2011) Responses of evergreen and deciduous Quercus species to enhanced ozone levels. Environ Poll 159: 55-63

Calderòn Guerrero CC, Günthardt-Goerg MS, Vollenweider P (2013) Foliar symptoms triggered by ozone stress in irrigated holm oaks from the city of Madrid, Spain. PLoS One 8: e69171

Camarero JJ, Olano JM, Arroyo Alfaro SJ, Fernández-Marín B, Becerril JM, García-Plazaola JI (2012) Photoprotection mechanisms in Quercus ilex under contrasting climatic conditions. Flora 207: $557-564$

Corcobado T, Cubera E, Juárez E, Moreno G, Solla A (2014) Drought events determine performance of Quercus ilex seedlings and increase their susceptibility to Phytophthora cinnamomi. Agr Forest Meteorol 192-193: 1-8

Crescente MF, Gratani L, Larcher W (2002) Shoot growth efficiency and production of Quercus ilex L. in different climates. Flora 197: 2-9

Damesin C, Rambal S (1995) Field study of leaf photosynthetic performance by a Mediterranean deciduous oak tree (Quercus pubescens) during a severe summer drought. New Phytol 131: 159_ 167

Desotgiu R, Pollastrini M, Cascio C, Gerosa G, Marzuoli R, Bussotti F (2012) Chlorophyll a fluorescence analysis along a vertical gradient of the crown in a poplar (Oxford clone) subjected to ozone and water stress. Tree Physiol 32: 976-986

Döring AS, Pellegrini E, Campanella A, Trivellini A, Gennai C, Petersen M, Nali C, Lorenzini G. (2014) How sensitive is Melissa officinalis to realistic ozone concentration. Plant Physiol Biochem 74: 156-164

Dumont J, Spicher F, Montpied P, Dizengremel P, Jolivet Y, Le Thiec D (2013) Effects of ozone on stomatal responses to environmental parameters (blue light, red light, $\mathrm{CO}_{2}$ and vapour pressure deficit) in three Populus deltoides $\times$ Populus nigra genotypes. Environ Poll 173: 85-96

Filippou P, Bouchagier P, Skotti E, Fotopoulos V (2014) Proline and reactive oxygen/nitrogen species

This article is protected by copyright. All rights reserved. 
metabolism is involved in the tolerant response of the invasive plant species Ailanthus altissima to drought and salinity. Environ Exp Bot 97: 1-10

Fini A, Guidi L, Ferrini F, Brunetti C, Di Ferdinando M, Biricolti S, Pollastri S, Calamai L, Tattini M (2012) Drought stress has contrasting effects on antioxidant enzymes activity and phenylpropanoid biosynthesis in Fraxinus ornus leaves: An excess light stress affair? J Plant Physiol 169: 929-939

Fini A, Bellasio C, Pollastri S, Tattini M, Ferrini F (2013) Water relations, growth, and leaf gas exchange as affected by water stress in Jatropha curcas. J Arid Environ 89: 21-29

Flexas J, Escalona JM, Evain S, Gulias J, Moya I, Osmond CB, Medrano H (2002) Steady-state chlorophyll fluorescence $\left(\mathrm{F}_{\mathrm{s}}\right)$ measurements as a tool to follow variations of net $\mathrm{CO}_{2}$ assimilation and stomatal conductance during water-stress in $\mathrm{C}_{3}$ plants. Physiol Plant 114: 231-240

García-Plazaola JI, Artetxe U, Duñabeitia MK, Becerril JM (1999) Role of photoprotective systems of holm-oak (Quercus ilex) in the adaptation to winter conditions. J Plant Physiol 155: 625-630

Genty B, Briantais JM, Baker NR (1989) The relationship between the quantum yield of photosynthetic electron transport and quenching of chlorophyll fluorescence. Biochim Biophys Acta 990: 87-92

Gerosa G, Marzuoli R, Finco A, Monga R, Fusaro L, Faoro F (2014) Contrasting effects of water salinity and ozone concentration on two cultivars of durum wheat (Triticum durum Desf.) in Mediterranean conditions. Environ Poll 193: 13-21

Gimeno TE, Pías B, Lemos-Filho P, Valladares F, 2008. Plasticity and stress tolerance override local adaptation in the responses of Mediterranean holm oak seedlings to drought and cold. Tree Physiol 29: 87-98

Gottardini E, Cristofori A, Cristofolini F, Nali C, Pellegrini E, Bussotti F, Ferretti M (2014) Chlorophyll-related indicators are linked to visible ozone symptoms: evidence from a filed study on native Viburnum lantana L. plants in northern Italy. Ecol Indic 39: 65-74

Gratani L, Catoni R, Varone L (2013) Morphological, anatomical and physiological leaf traits of Q. ilex, P. latifolia, P. lentiscus, and M. communis and their response to Mediterranean climate stress factors. Bot Stud 54: 35-46

Gratani L, Pesoli P, Crescente MF, Aichner K, Larcher W (2000) Photosynthesis as a temperature indicator in Quercus ilex L. Global Planet Change 24: 153-163

Grünehage L, Jäger H-J (2003) From critical levels to critical loads for ozone: a discussion of a new experimental and modelling approach for establishing flux-response relationships for agricultural crops and native plant species. Environ Poll 125: 99-110

Guidi L, Degl'Innocenti E, Remorini D, Biricolti S, Fini A, Ferrini F, Nicese FP, Tattini M (2011) The impact of UV-radiation on the physiology and biochemistry of Ligustrum vulgare exposed to different visible-light irradiance. Environ Exp Bot 70: 88-95

Haberer K, Herbinger K, Alexou M, Rennenberg H, Tausz M (2008) Effects of drought and canopy

This article is protected by copyright. All rights reserved. 
ozone exposure on antioxidants in fine roots of mature European beech (Fagus sylvatica). Tree Physiol 28: 713-719

Harb A, Krishnan A, Ambavaram MMR, Pereira A (2010) Molecular and physiological analysis of drought stress in Arabidopsis reveals early responses leading to acclimation in plant growth. Plant Physiol 154: 1254-1271

Hoshika Y, Omasa K, Paoletti E (2013a) Both ozone exposure and soil water stress are able to induce stomatal sluggishness. Environ Exp Bot 88: 19-23

Hoshika Y, Watanabe M, Inada N, Koike T (2013b) Model-based analysis of avoidance of ozone stress by stomatal closure in Siebold's beech (Fagus crenata). Ann Bot 112: 1149-1158

Hoshika Y, Watanabe M, Inada, N, Koike T (2012) Ozone-induced stomatal sluggishness develops progressively in Siebold's beech (Fagus crenata). Environ Poll 166: 152-156

Hu L, Wang Z, Huang B (2010) Diffusion limitations and metabolic factors associated with inhibition and recovery of photosynthesis from drought stress in a C3 perennial grass species. Physiol Plant 139: 93-106

Inclán R, Ribas A, Penuelas J, Gimeno BS, 1999. The relative sensitivity of different Mediterranean plant species to ozone. Water Air Soil Poll 116: 273-277

Jubani-Marí T, Munné-Bosch S, Alegre L (2010) Redox regulation of water stress responses in fieldgrown plants. Roles of hydrogen peroxide and ascorbate. Plant Physiol Biochem 48: 351-358

Kronfuss G, Polle A, Tausz M, Havranek WM, Wieser G (1998) Effects of ozone and mild drought stress on gas exchange, antioxidants and chloroplast pigment in current-year needles of young Norway spruce (Picea abies [L.] Karst.). Trees 12: 482-489

Kurz C, Schmieden U, Strobel P, Wild A (1998) The combined effect of $\mathrm{CO}_{2}$, ozone and drought on the radical scavenging system of young oak trees (Quercus petraea) - a phytothron study. Chemosphere 36: 783-788

Li L, Manning WJ, Tong L, Wang X (2015) Chronic drought stress reduced but not protected Shantung maple (Acer truncatum Bunge) from adverse effects of ozone $\left(\mathrm{O}_{3}\right)$ on growth and physiology in the suburb of Beijing, China. Environ Pollut 201: 34-41

Manes F, Vitale M, Donato E, Giannini M, Puppi G (2006) Different ability of three Mediterranean oak species to tolerate progressive dehydration stress. Photosynthetica 44: 387-393

Manes F, Vitale M, Donato E, Paoletti E (1998) $\mathrm{O}_{3}$ and $\mathrm{O}_{3}+\mathrm{CO}_{2}$ effects on a Mediterranean evergreen broadleaf tree holm oak (Quercus ilex L.). Chemosphere 36: 801-806

Matesanz S, Valladares F (2014) Ecological and evolutionary responses of Mediterranean plants to global change. Environ Exp Bot 103: 53-67

Matyssek R, Le Thiec D, Löw M, Dizengremel P, Nunn AJ, Häberle KH (2005) Interactions between drought stress and $\mathrm{O}_{3}$ in forest trees. Plant Biol 7: 1-7

Munné-Bosch S, Alegre L (2000) Changes in carotenoids, tocopherols and diterpenes during drought and recovery, and the biological significance of chlorophyll loss in Rosmarinus officinalis plants.

This article is protected by copyright. All rights reserved. 
Planta 210: 925-931

Nali C, Paoletti E, Marabottini R, Della Rocca G, Lorenzini G, Paolacci AR, Ciaffi M, Badiani M (2004) Ecophysiological and biochemical strategies of response to ozone in Mediterranean evergreen broadleaf species. Atmos Environ 38: 2247-2257

Nardini A, Pitt F (1999) Drought resistance of Quercus pubescens as a function of root hydraulic conductance, xylem embolism and hydraulic architecture. New Phytol 143: 485-493

Niinemets U, Keenan T (2014) Photosynthetic responses to stress in Mediterranean evergreens: Mechanisms and models. Environ Exp Bot 103: 24-41

Nikolova PS, Andersen CP, Blaschke H, Matyssek R, Häberle K-H (2010) Facing the future: evidence from joint AspenFACE, SoyFACE and SFB 607 Meeting. Environ Poll 158: 1071-1078

Pearson M and Mansfiled TA (1993) Interacting effects of ozone and water stress on the stomatal resistance of beech (Fagus sylvatica L.) New Phytol 123: 351-358

Pellegrini E, Trivellini A, Campanella A, Francini A, Lorenzini G, Nali C, Vernieri P (2013) Signaling molecules and cell death in Melissa officinalis plants exposed to ozone. Plant Cell Rep 32: 19651980

Pesoli P, Gratani L, Larcher W (2003) Responses of Quercus ilex from different provenances to experimentally imposed water stress. Biol Plant 46: 577-581

Pinheiro C, Chaves MM (2011) Photosynthesis and drought: can we make metabolic connections from available data? J Exp Bot 62: 869-882

Pollastrini M, Desotgiu R, Camin F, Ziller L, Gerosa G, Marzuoli R, Bussotti F (2014) Severe drought events increase the sensitivity to ozone on poplar clones. Environ Exp Bot 100: 94-104

Pollastrini M, Desotgiu R, Camin F, Ziller L, Marzuoli R, Gerosa G, Bussotti F (2013) Intra-annual pattern of photosynthesis, growth and stable isotope partitioning in a poplar clone subjected to ozone and water stress. Water Air Soil Pollut 224: 1761-1772

Ribas A, Peñuelas J, Elvira S, Gimeno BS (2005a) Ozone exposure induces the activation of leaf senescence-related processes and morphological and growth changes in seedlings of Mediterranean tree species. Environ Poll 134: 291-300

Ribas A, Peñuelas J, Elvira S, Gimeno BS (2005b) Contrasting effects of ozone under different water supplies in two Mediterranean tree species. Atmos Environ 39: 685-693

Sharkey TD (1985) Photosynthesis in intact leaves of C3 plants: physics, physiology and rate limitations. Bot Rev 51: 53-105

Tognetti R, Cherubini P, Marchi S, Raschi A (2007) Leaf traits and tree rings suggest different wateruse and carbon assimilation strategies by two co-occurring Quercus species in a Mediterranean mixed-forest stand in Tuscany, Italy. Tree Physiol 27: 1741-1751

Tsonev T, Wahbi S, Sun P, Sorrentino G, Centritto M (2014) Gas exchange, water relations and their relationships with photochemical reflectance index in Quercus ilex plants during water stress and recovery. Int J Agri Biol 16: 335-341

This article is protected by copyright. All rights reserved. 
Turner NC, Long MJ (1980) Errors arising from rapid water loss in the measurement of leaf water potential by the pressure chamber technique. Aust J Plant Physiol 7: 527-537

Vahisalu T, Puzõrjova I, Brosché M, Valk E, Lepiku M, Moldau H, Pechter P, Wang Y-S, Lindgren O, Salojärvi J, Loog M, Kangasjärvi J, Kollist H (2010) Ozone-triggered rapid stomatal response involves the production of reactive oxygen species, and is controlled by SLAC1 and OST1. Plant J 62: 442-453

Valladares F, Balaguer L, Martinez-Ferri E, Perez-Corona E, Manrique E (2002) Plasticity, instability and canalization: is the phenotypic variation in seedlings of sclerophyll oaks consistent with the environmental unpredictability of Mediterranean ecosystems? New Phytol 156: 457-467

Valladares F, Gianoli E, Gómez JM (2007) Ecological limits to plant phenotypic plasticity. New Phytol 176: 749-763

Valladares F, Pearcy RW (2002) Drought can be more critical in the shade than in the sun: a field study of carbon gain and photo-inhibition in a Californian shrub during a dry El Niño year. Plant Cell Environ 25: 749-759

Valladares F, Wright SJ, Lasso E, Kitajima K, Pearcy RW (2000) Plastic phenotypic response to light of 16 congeneric shrubs from a Panamanian rainforest. Ecology 81: 1925-1936

Vitale M, Salvatori E, Loreto F, Fares S, Manes F (2008) Physiological responses of Quercus ilex leaves to water stress and acute ozone exposure under controlled conditions. Water Air Soil Pollut 189: $113-125$

This article is protected by copyright. All rights reserved. 


\section{Figure legends}

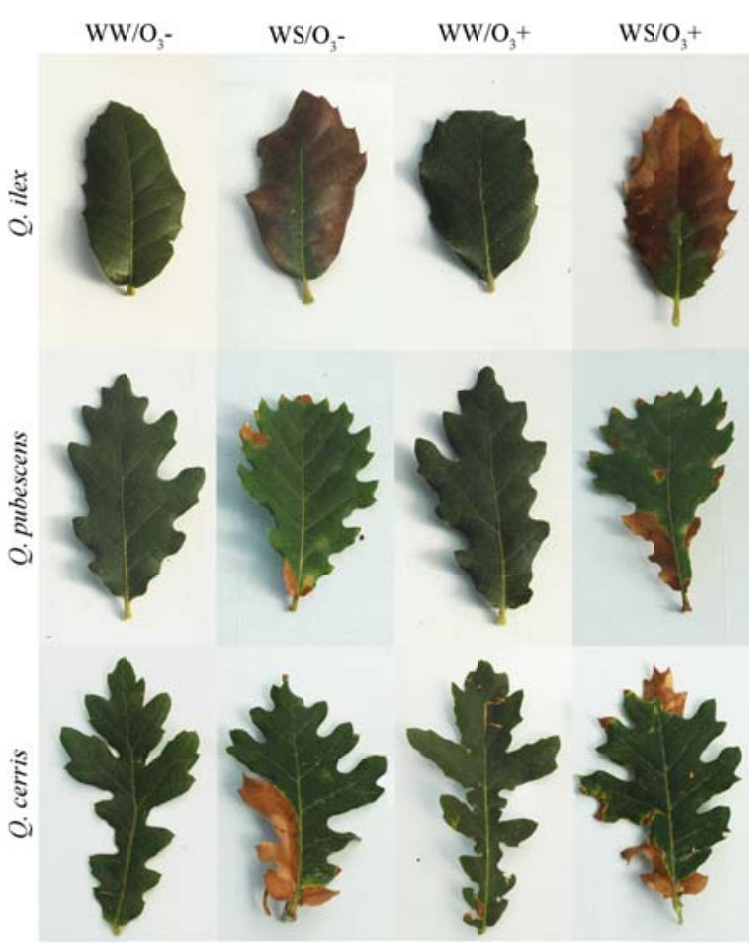

Fig. 1. Symptoms in leaves of Quercus ilex, Q. pubescens and Q. cerris exposed to drought (daily irrigation with $30 \%$ of effective evapotranspiration; WS/O ${ }_{3}^{-}$), ozone ( $80-100 \mathrm{nl}^{-1}$ for 77 consecutive days, $\left.5 \mathrm{~h} \mathrm{day}^{-1} ; \mathrm{WW} / \mathrm{O}_{3}+\right)$ and drought $\times$ ozone $\left(\mathrm{WS} / \mathrm{O}_{3}+\right)$. Controls were kept in charcoal-filtered air and were well watered $\left(\mathrm{WW} / \mathrm{O}_{3}-\right)$. 

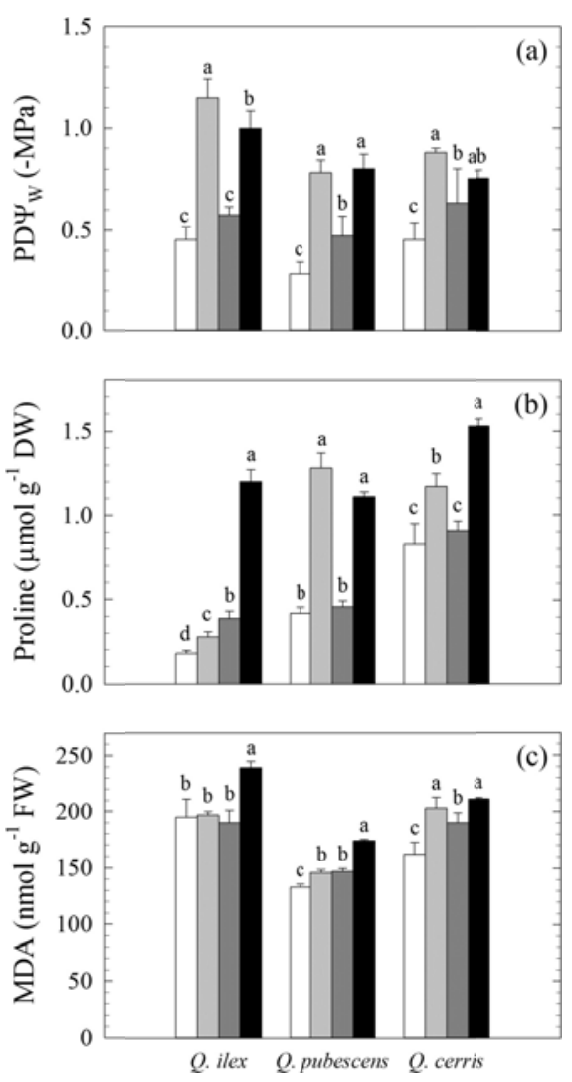

Fig. 2. Pre-dawn water potential $\left(\mathrm{PD} \Psi_{\mathrm{w}}\right.$; a), leaf proline content (b) and malondialdehyde (MDA) byproducts (c) estimated in Quercus ilex, Q. pubescens and Q. cerris plants exposed to drought (daily irrigation with $30 \%$ of effective evapotranspiration; grey bars), ozone (80-100 $\mathrm{nl}^{-1}$ for 77 consecutive days, $5 \mathrm{~h} \mathrm{day}^{-1}$; dark grey bars) and drought $\times$ ozone (black bars). Controls were kept in charcoalfiltered air and were well watered (white bars). Data are shown as mean \pm standard deviation $(n=3)$. For each plant species letters above bars indicate significant differences between drought and $\mathrm{O}_{3}$ when $\mathrm{P}<0.05$ (see Table S2). Abbreviations: DW, dry weight; FW, fresh weight.

This article is protected by copyright. All rights reserved. 
Q. ilex
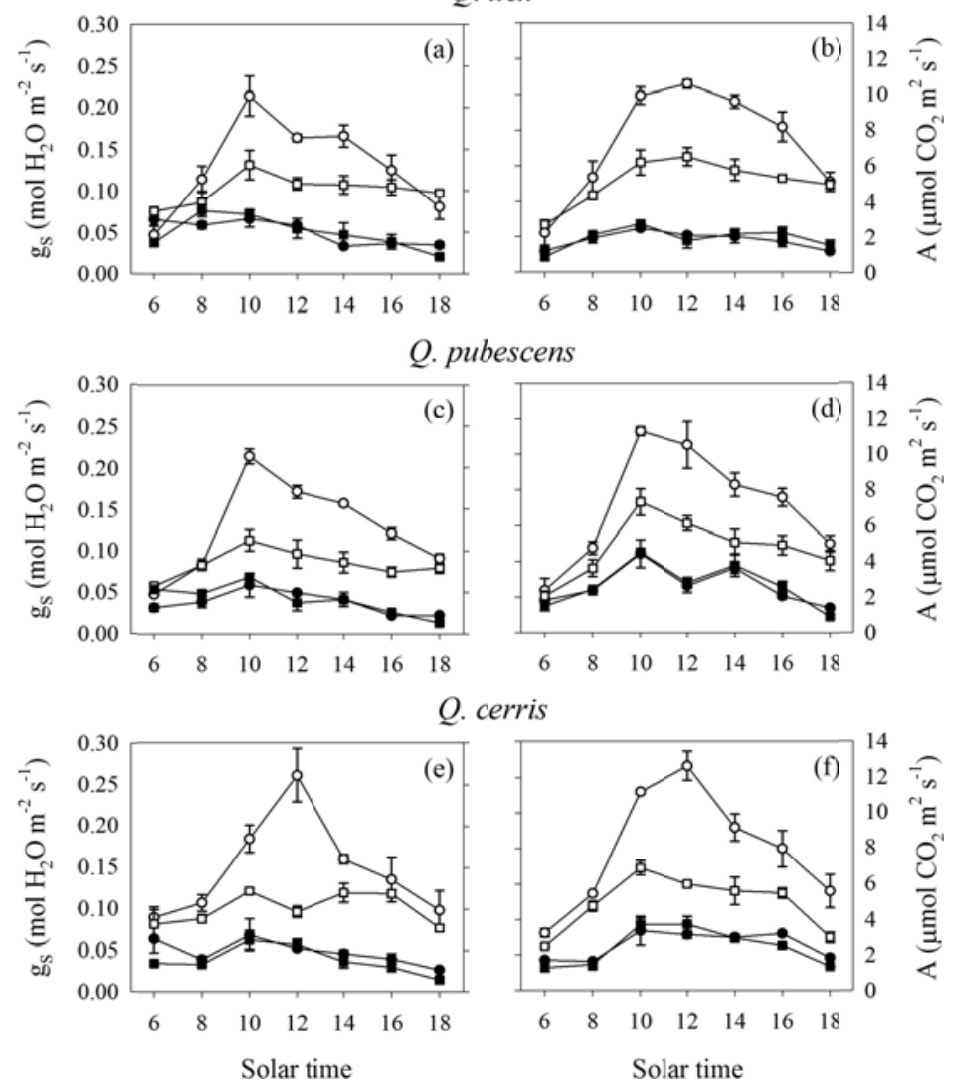

Fig. 3. Daily leaf photosynthesis (A) and stomatal conductance ( $\mathrm{g}_{\mathrm{s}}$ ) in Quercus ilex, Q. pubescens and Q. cerris plants exposed to drought (daily irrigation with $30 \%$ effective evapotranspiration; closed circle), ozone (80-100 $\mathrm{nl} \mathrm{l}^{-1}$ for 77 consecutive days, $5 \mathrm{~h} \mathrm{day}^{-1}$; open square) and drought $\times$ ozone (closed square). Controls were kept in charcoal-filtered air and were well watered (open circle). Data are shown as mean \pm standard deviation $(n=3)$.
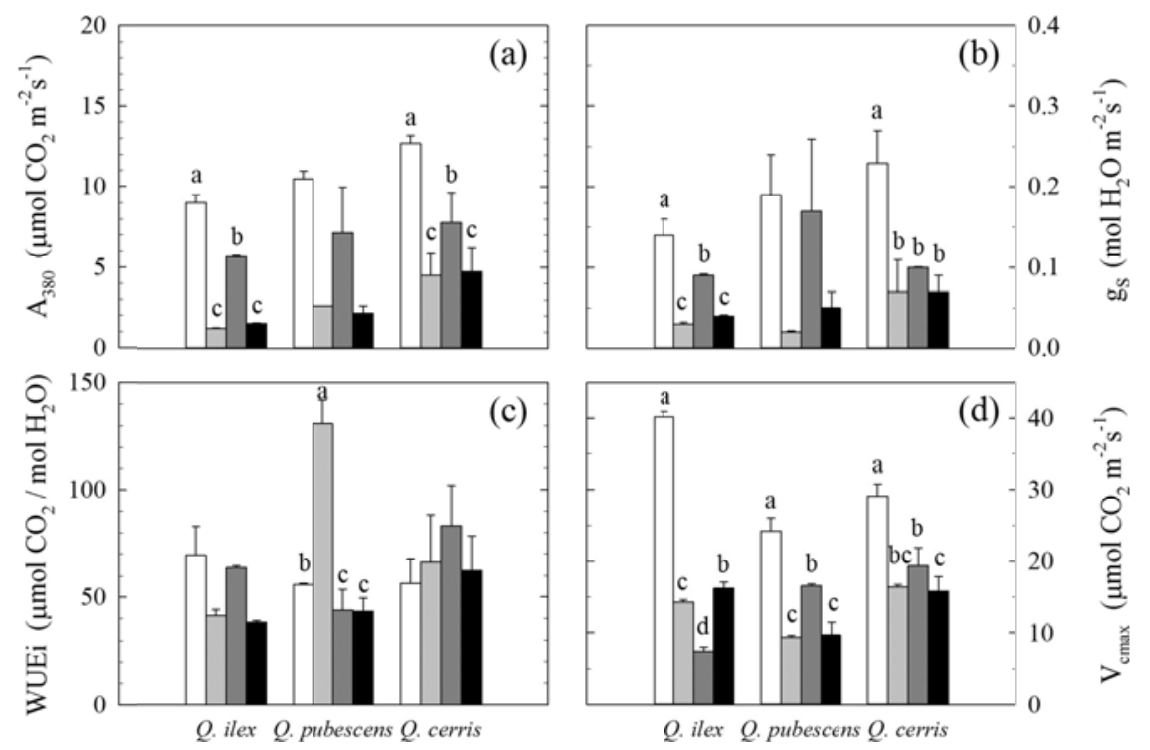

Fig. 4. Foliar gas exchange parameters in Quercus ilex, Q. pubescens and Q. cerris plants exposed to drought (daily irrigation with $30 \%$ of effective evapotranspiration; grey bars), ozone (80-100 $\mathrm{nl}^{-1}$ for 
77 consecutive days, $5 \mathrm{~h} \mathrm{day}^{-1}$; dark grey bars) and drought $\times$ ozone (black bars). Controls were kept in charcoal-filtered air and were well-watered (white bars). Data are shown as mean \pm standard deviation $(n=3)$. For each plant species letters above bars indicate significant differences between drought and $\mathrm{O}_{3}$ when $\mathrm{P}<0.05$ (see Table S2). Abbreviations: $\mathrm{A}_{380}, \mathrm{CO}_{2}$ assimilation rate at light saturation (a); $g_{s}$, stomatal conductance to water vapor (b); $\mathrm{WUE}_{i}$, intrinsic water use efficiency (c); apparent $\mathrm{V}_{c \max }$, maximum rate of carboxylation (d).
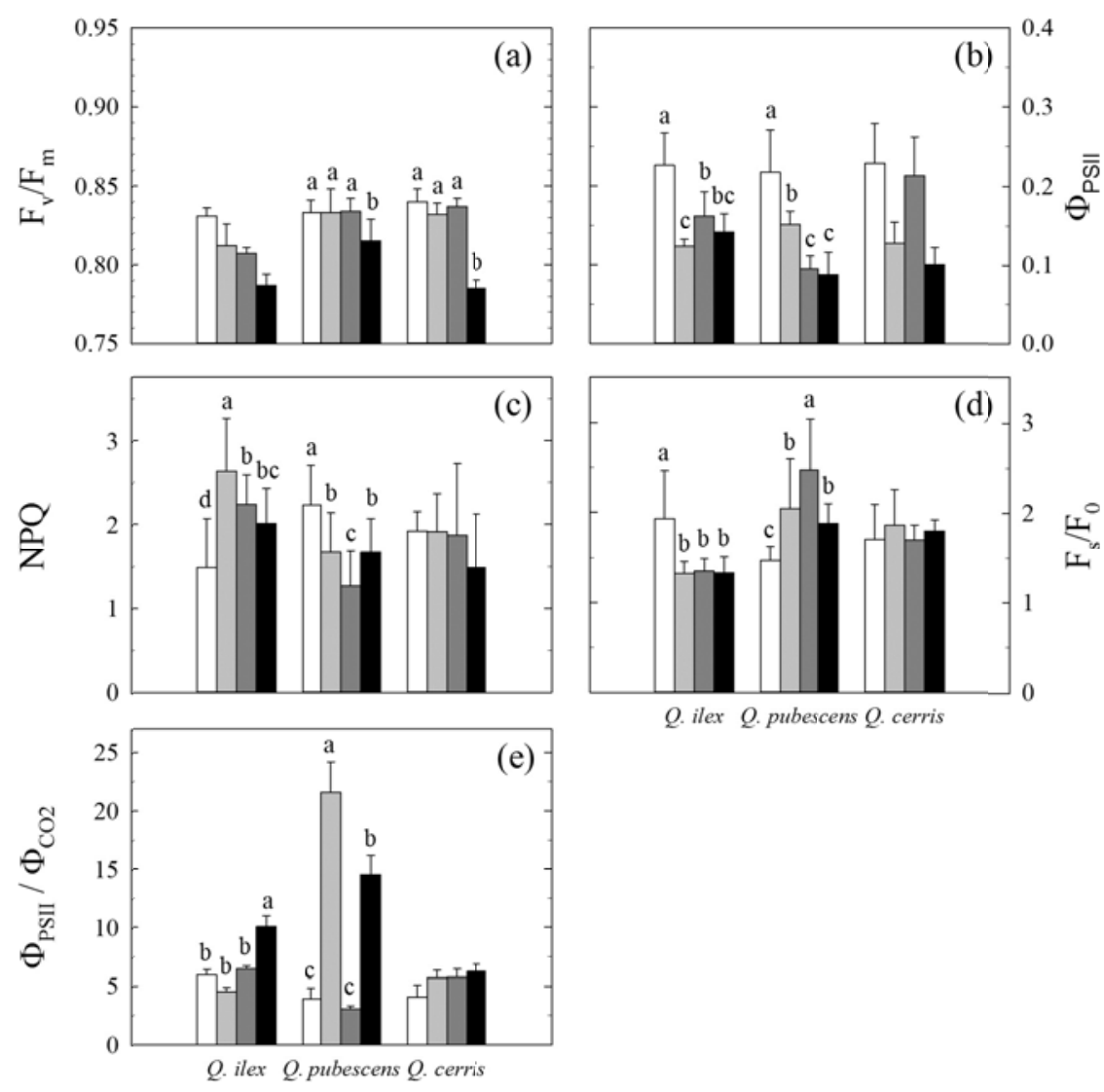

Fig. 5. Leaf chlorophyll a fluorescence parameters in Quercus ilex, Q. pubescens and Q. cerris plants exposed to (daily irrigation with $30 \%$ effective evapotranspiration; grey bars), ozone ( $80-100 \mathrm{nl}^{-1}$ for 77 consecutive days, $5 \mathrm{~h} \mathrm{day}^{-1}$; dark grey bars) and drought $\times$ ozone (black bars). Controls were kept in charcoal-filtered air and were well watered (white bars). Data are shown as mean \pm standard deviation $(n=6)$. For each plant species letters above bars indicate significant differences between drought and $\mathrm{O}_{3}$ when $\mathrm{P}<0.05$ (see Table S2). Quenching analysis parameters are determined at a light intensity of about $600 \mu \mathrm{mol}$ photon $\mathrm{m}^{-2} \mathrm{~s}^{-1}$. Abbreviations: $\mathrm{F}_{\mathrm{v}} / \mathrm{F}_{\mathrm{m}}$, potential PSII photochemical activity (a); $\Phi_{\text {PSII }}$, actual PSII photochemical activity (b); NPQ, non-photochemical quenching (c); $\mathrm{F}_{\mathrm{s}} / \mathrm{F}_{0}$, steady-state fluorescence value normalized to minimal fluorescence (d); $\Phi_{\mathrm{PSII}} / \Phi_{\mathrm{CO} 2}$ ratio (e).

This article is protected by copyright. All rights reserved. 
